in the Large White Herdbook. Differences among herds subject to important time vàriations are responsible for a significant herd $\times$ season interaction. The joint action of these two effects remains moderate for characters related to sow prolificacy ( 5 to $7 \mathrm{p}$. Ioo of their variance) but becomes decidedly more marked for characters related to growth of the piglets $\left(22\right.$ to $4^{\circ} \mathrm{p}$. Ioo of their variance). The effect of sequence number of the litter is significant for all the variables, and shows up essentially as a distinct improvement from the first to the second litter. Month of birth and boar have little importance. Estimates of heritability by two different methods are low and range between $0,0 \mathrm{I}$ and $\mathrm{o,I}$. Estimates of repetability range between 0,09 and 0,16 . Correlations between variables emphasize the important influence of litter size on the productivity of the sow. The possibility is considered of classifiying sows in each herd according to productive ability.

\title{
RECHERCHE D'UN TAUX OPTIMUM DE SÉLECTION DES JEUNES TRUIES SUR LA PROLIFICITÉ DE LEUR MÈRE
}

\author{
C. LEGAULT \\ Laboratoire de Génétique quantitative et appliquée, \\ Centre national de Recherches zootechniques, 78 -Jouy-en-Josas \\ Institut national de la Recherche agronomique
}

\section{RÉSUMÉ}

La faible héritabilité de la prolificité des truies suffit-€lle à exclure ce caractère de la sélection à l'avantage exclusif des performances d'engraissement et de carcasse? Plaçons-nous dans une unité de production mixte (naisseur-engraisseur) et supposons que toute jeune truie peut être classée en fonction de deux critères de sélection : l'indice de prolificité de sa mère et un indice de sélection individuel combinant gain moyen quotidien et épaisseur du lard dorsal. On démontre que le taux de sélection applicable au second critère $\left(\mathrm{P}^{\prime}\right)$ ainsi que le progrès économique réalisé annuellement par sélection $(\Delta \mathrm{E})$ sont des fonctions de $(\mathrm{P})$, le taux de sélection appliqué au premier critère. Par ailleurs la courbe représentative de $\Delta \mathrm{E}$ passe par un maximum correspondant au taux de sélection optimum $\left(\mathrm{P}_{m}\right)$ sur la prolificité des truies mères. La valeur de $\left(\mathrm{P}_{m}\right)$ dépend étroitement du coût du contrôle de la jeune truie dans l'élevage (pesées et mesure du lard dorsal). Par ailleurs l'intérêt de la sélection sur la prolificité décroît en valeur relative lorsque le niveau de productivité numérique du troupeau augmente. Pour un coût moyen du contrôle de $2 \mathrm{~F}$ par jeune truie, $\mathrm{P}_{m}=0,45$ et la sélection sur la prolificité augmente de $\mathrm{I} 8 \mathrm{p}$. Ioo le profit d'une sélection basée uniquement sur le $z^{\text {e }}$ critère. Pratiquement dans les conditions moyennes de l'élevage français il est conseillé à l'éleveur d'éliminer la moitié de ses jeunes truies d'après la prolificité de leur mère et d'assurer le renouvellement du troupeau avec le $\mathrm{r} / 6$ des jeunes truies restantes classées sur leur croissance et leur adiposité. 


\title{
SUMMARY
}

\section{OPTIMUM SELECTION RATE OF GILTS ON THE PROLIFICACY OF THEIR MOTHER}

Can selection on prolificacy of sows be economically advantageous in spite of its low heritability? Let-us suppose that gilts can be classified either on prolificacy index of their mother or on an individual index combining growth rate and back fat thickness. Selection rate on the second criterion and total genetic progress $(\Delta E)$ are both fonctions of $(P)$ the selection rate on the first criterion. The tepresentative curve of $\Delta \mathrm{E}$ shows up a maximum value corresponding to an optimum value of $\mathrm{P}:\left(\mathrm{P}_{m}\right) . \mathrm{P}_{m}$ depends on the cost of the control of the gilt and the farm (weight and backfat measurements). Moreover the relative advantage of selection on prolificacy decreases as the prolificacy level of the herd increases. For a mean value of the cost of the control of $2 \mathrm{~F} / \mathrm{gilt}$ $\mathrm{P}_{m}=0.45$ and selection on prolificacy increases by $\mathbf{I} 8 \mathrm{p}$. Ioo the benefit of a selection based only on growth rate and backfat thickness. French breeders are advised to cull half of the gilts according to prolificacy of their mother and to select $\mathrm{r} / 6$ of the remaining gilts according to their individual index.

\section{PATHOLOGIE}

\section{LA GASTRO-ENTÉRITE DE DOYLE ET HUTCHINGS}

\author{
Ph. COTTEREAU \\ Chaire de Pathologie médicale du Bétail et des Animaux de Basse-Cour, \\ École nationale vétérinaire, 2, quai Chauveau, 69 -Lyon \\ Institut national de la Recherche agronomique
}

\section{RÉSUMÉ}

L'auteur définit la maladie et montre l'importance qu'elle présente, notamment un taux de mortalité de roo p. roo chez les porcelets âgés de moins de 5 jours. Il rappelle qu'il fut le premier en France à identifier l'existence de la maladic en 1962. Il fait ensuite, la description clinique de 